\title{
Role of Glutathione S-transferase $M u 1$ and Glutathione S-transferases Theta 1 Polymorphism in the Risk of Developing Type 2 Diabetes Mellitus at Universitas Sumatera Utara Hospital, Medan
}

\author{
Zaimah Z. Tala ${ }^{1}$ (D), Mutiara Indah Sari ${ }^{2 *}$ (D) \\ ${ }^{1}$ Department of Clinical Nutrition, Faculty of Medicine, Universitas Sumatera Utara, Medan, Indonesia; ${ }^{2}$ Department of \\ Biochemistry, Faculty of Medicine, Universitas Sumatera Utara, Medan, Indonesia
}

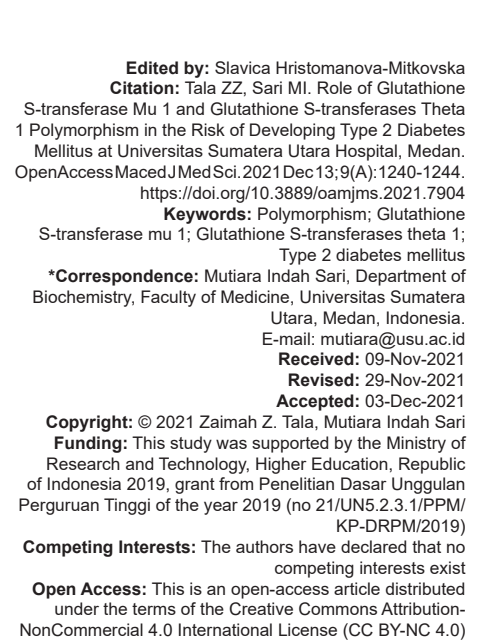

\begin{abstract}
BACKGROUND: Diabetes mellitus (DM) is associated with an increased production of reactive oxygen species and a reduction in antioxidant defense. Glutathione S-transferases (GSTs) is group of multifunction antioxidant enzyme can be used as important biomarkers for DM. GSTM1, T1 genes variant polymorphism result in decreased or loss of enzyme activity.

AIM: The study aimed to evaluate the role of GST mu 1 (GSTM1) and GST theta 1 (GSTT1) gene polymorphism in the risk of developing T2DM.

METHODS: GSTM1 and GSTT1 polymorphisms were genotyped in 87 type 2 DM (T2DM) patients and 87 healthy control group to analyze their association with T2DM susceptibility using multiplex polymerase chain reaction (PCR) PCR products were electrophoresed using agarose $2 \%$. Odds ratio $(\mathrm{OR})$ with $95 \%$ confidence interval $(\mathrm{Cl})$ and p-value were calculated using Statistical Package for the Social Sciences software (version 21.0).

RESULTS: The genotype distribution of GSTM1 and GSTT1 was not different between T2DM patients and healthy control group $(p=0.542, \mathrm{OR}=0.780, \mathrm{Cl} 95 \%=0.350-1.737$ and $\mathrm{p}=0.879, \mathrm{OR}=1.047, \mathrm{Cl} 95 \%=0.577-1.903$ ). The genotype distribution of combination of GSTM1 and GSTT1 were also not different between T2DM patients and healthy control group $(p=0.640, \mathrm{OR}=0.640, \mathrm{Cl} 95 \%=0.224-1.83$ and $p=0.551, \mathrm{OR}=0.721, \mathrm{Cl} 95 \%=0.245-2.120$. CONCLUSION: In summary, this study showed that GSTT1 null, GSTM1 null, the combination of GSTM1 null and GSTT1 null genotype or combination of GSTM1 null and GSTT1 positive (or contrary) did not have any risk of developing T2DM at Universitas Sumatera Utara Hospital, Medan.
\end{abstract}

\section{Introduction}

Diabetes mellitus (DM) is a chronic metabolic syndrome with symptoms of increased blood glucose levels or hyperglycemia. In DM, hyperglycemia occurs when there is a failure of endocrine gland to secrete adequate insulin to meet metabolic needs. This condition is caused by beta cell secretory dysfunction and/or decreasing number of beta cell [1]. The data showed that the prevalence of DM throughout the world, including Indonesia, is increasing. The prevalence of DM in the world was predicted to be higher in 2045 about 700 millions cases compared to that in 2019 about 463 millions cases. In Indonesia, the prevalence was predicted to increasing from 10.7 millions in 2019 become 16.6 million people suffering DM in 2045 [2], [3].

DM pathogenesis involves some molecules such as increasing reactive oxygen species (ROS) which is a compound formed by physiology oxidation process in cellular level. ROS is a compound that has one or more unpaired atom. Some types of ROS are superoxide $\left(\mathrm{O}^{-}\right)$, hydrogen peroxidase $\left(\mathrm{H}_{2} \mathrm{O}_{2}\right)$, and hydroxyl radical $\left(\mathrm{OH}^{-}\right)$. Excessive ROS formation causes a stress oxidative to protein, lipid and DNA. It causes damage and impaired cell function, such as pancreas cell failure to produce and secrete insulin. Molecular modification for solving the disruption can cause imbalance in antioxidant (antioxidant defense). ROS can be eliminated by some mechanism of enzymatic and non-enzymatic antioxidant [4], [5].

Antioxidant is a substance that has an important role in human body because of its function that inhibits and neutralizes oxidation reaction involving ROS. The inhibitory mechanism of antioxidant usually occurs when this reaction is useless or propagation in the oxidation reaction of lipids or other molecules inside body by absorbs and neutralizes ROS compound [5]. One of the antioxidants, involved in ROS compound detoxification, is glutathione S-transferases (GSTs). GST, a group of multifunction antioxidant enzyme and glutathione $(\mathrm{GSH})$ have an important role in electrophilic 
substrate detoxification by phase II detoxification system [6].

A previous study has evidence in association of GST level with increasing stress oxidative. One of the GST isoforms is GST mu 1 (GSTM1) encode by GST $\mu$. The GSTM1 gene located in chromosome 1p13.3. Another GSTs isoform are GST theta 1 (GSTT1) encoded by GST $\theta$. The GSTT1 gene located in chromosome 22q11.2 [6], [7]. GSTM1 and GSTT1 null genotype were associated with the decrease in enzyme activity and related to GSH antioxidant level of changes [8], [9]. The previous study showed that GSTM1 and GSTT1 gene polymorphism had an impact on some certain diseases [10], [11], [12], [13]. Several populations in the world showed that GSTM1 gene null polymorphism and/or GSTT1 had the risk of type 2 DM (T2DM) compared with healthy control group [14], [15]. GSTT1 dan GSTM1 gene polymorphism and some diseases have been studied in Indonesia [16], [17], [18], [19], however, so far not research on T2DM. Therefore, this study was aimed to determine the role of GSTM1 and GSTT1 gene polymorphism in T2DM at Universitas Sumatera Utara Hospital, Medan, Indonesia.

\section{Methods}

This study included 87 T2DM patients who were treated in Endocrinology Polyclinic at Universitas Sumatera Utara hospital, Medan, Indonesia. The diagnosis was based on the PERKENI (Indonesian Society of Endocrinology) as the case group. The patient was obtained based on specific inclusion and exclusion criteria. Healthy control group consists of 87 gymnastic participants in Medan. The study was conducted after due approval of Faculty of Medicine, Universitas Sumatera Utara-RSUP Haji Adam Malik ethics committee (ethics number: 447/TGL/KEPK FK USU-RSUP-HAM/2019).

This study was an observational with crosssectional study design. T2DM patients obtained from Endocrinology Polyclinic at Universitas Sumatera Utara hospital, Medan, Indonesia. Healthy subjects, in this study, were gym participants from several gyms in Medan city, North Sumatera Province, Indonesia.

Fasting and $2 \mathrm{~h}$ postprandial (2 h-PP) blood glucose obtained from whole blood, blood serum, and buffy coat from the sample study. Fasting blood glucose, 2 h-PP and HbA1c were tested in Universitas Sumatera Utara hospital according to their routine procedure. The genotyping of GSTM1 and GSTT1 and gene polymorphism was conducted in Biomolecular Laboratory, Faculty of Medicine, Universitas Sumatera Utara. There were several steps for genotyping, that is, DNA extraction using DNA extraction kit (Promega, USA), the isolated DNA concentration and purification were measured at 260/280 absorbent. DNA was kept in $-80^{\circ} \mathrm{C}$ for analyzing.

Screening for GSTM1 and GSTT1 null genotype was done using multiplex Polymerase Chain Reaction. Details of primers sequence were as follows:

- $\quad$ GSTM1 primers: Forward5'GAACTCCCTGAAAAGCTAAAGC-3'; Reverse, 5'-GTTGGGCTCAAATATACGGTGG- 3' GSTT1 primers: Forward 5'-TTCCTTACTGGTCCTCACATCTC-3'; Reverse, 5'-TCACCGGATCATGGC CAGCA-3'

- $\quad \beta$-actin primers: Forward 5'-AATGTGAACATGTGGGACTTTGTG-3'; Reverse, 5'-CGCCAGTTCAGGACATTAGGAC-3'as GSTM1 and GSTT1 control.

Briefly, PCR reaction was done in $25 \mu \mathrm{L}$ consist of $1 \mu \mathrm{L}$ each primer, $12.5 \mu \mathrm{L}$ GoTaq $\circledast$ Green Master Mix (Promega, USA), $1 \mu \mathrm{L}$ DNA sample, and add nuclease free water until the final volume was $25 \mu \mathrm{L}$. PCR was carried out with a primary denaturation step at $95^{\circ} \mathrm{C}$ for $5 \mathrm{~min}$, followed by 35 cycles of denaturation at $94^{\circ} \mathrm{C}$ for $30 \mathrm{~s}$, primer annealing at $63^{\circ} \mathrm{C}$ for $30 \mathrm{~s}$, elongation at $72^{\circ} \mathrm{C}$ for $30 \mathrm{~s}$, and a final elongation at $72^{\circ} \mathrm{C}$ for $10 \mathrm{~min}$ [10].

PCR products were analyzed by electrophoresed using agarose (Invitrogen) 1.5\% and ethidium bromide staining and were visualized using Ultra Violet transluminator. The result yielded fragment $215 \mathrm{bp}$ indicated GSTM1, fragment of $480 \mathrm{bp}$ indicated GSTT1, and $\beta$-actin control gene at $92 \mathrm{bp}$ [10].

The role of GSTM1 dan GSTT1 gene polymorphism in T2DM was assessed by Chi-square test with odds ratio $(\mathrm{OR})$ and confidence interval $(\mathrm{Cl})$ 95\% using Statistical Package for the Social Sciences (version 21.0).

\section{Results}

The participants consisted of 87 T2DM patients and 87 controls. The median of fasting glucose levels, $2 \mathrm{~h}$ PP level, and the HbA1c percentage in T2DM group compare with control group are $(194.5 \mathrm{mg} / \mathrm{dl}$ vs. $88.5 \mathrm{mg} / \mathrm{dl} ; 275.0 \mathrm{mg} / \mathrm{dl}$ vs. $119.0 \mathrm{mg} / \mathrm{dl} ; 9.1 \%$ vs. $5.4 \%$ ), respectively. The subject characteristic in T2DM group and healthy control group can be seen at Table 1 .

Table 1: Characteristic of study population

\begin{tabular}{lll}
\hline Variables & T2DM $(\mathrm{n}=87)$ & \\
& Median/(min-max $)$ & Control $(\mathrm{n}=87)$ \\
& Median/(min-max $)$ \\
\hline Fasting glucose $(\mathrm{mg} / \mathrm{dl})$ & $194.5 /(63.0-540.0)$ & $88.5 /(60.0-118.0)$ \\
2 h postprandial $(2 \mathrm{~h}-\mathrm{PP})(\mathrm{mg} / \mathrm{dl})$ & $275.0 /(172.0-542.0)$ & $119.0 /(72.0-207.0)$ \\
HbA1c $(\%)$ & $9.1 /(5.8-14.0)$ & $5.4 /(4.9-6.2)$ \\
\hline T2DM: Type 2 diabetes mellitus. & &
\end{tabular}


From 174 subjects, it was found that the frequency of GSTM1 null genotype was higher than GSTM1 wild-type/positive genotype (83.3\% vs. $16.7 \%$ ), but in contrary, the frequency of GSTT1 null genotype was lower than GSTT1 positive genotype (45.4\% vs. $54.6 \%$ ). The differences of the genotype distribution in T2DM group and healthy control group can be seen at Table 2.

Table 2: Distribution of GSTM1 and GSTT1 genotypes in study subjects

\begin{tabular}{lll}
\hline Genotypes & $\mathrm{n}$ & $\%$ \\
\hline GSTM1 & & \\
Positive & 29 & 16.6 \\
$\quad$ Null & 145 & 83.4 \\
GSTT1 & 95 & 54.6 \\
Positive & 79 & 45.4 \\
$\quad$ Null & &
\end{tabular}

The frequency of GSTM1 positive genotype in T2DM patients was higher than healthy control group (18.4\% vs. $14.9 \%)$, while the frequency of GSTM1 null genotype in T2DM patients was lower than healthy control group $(81.6 \%$ vs. $85.1 \%)$. The frequency of GSTT1 positive genotype was lower in T2DM patients than healthy control group (54.0\% vs. $55.2 \%$ ), while the frequency of GSTT1 null genotype was higher in T2DM patients than healthy control group (46.0\% vs. $44.8 \%)$. The frequency data of GSTM1 and GSTT1 genotype in both groups and their combination are shown in Table 3. In present study, we observed that GSTT1 null genotype had no risk of developing T2DM (OR = 1.047; $95 \% \mathrm{Cl}=0.577-1.903 ; p=0.879)$. Neither GSTM1 null genotype, the combination of GSTM1 null and GSTT1 null genotype or combination of GSTM1 null and GSTT1 positive (or contrary) also did not have any risk of developing T2DM (Table 3).

Table 3: The comparison of GSTM1 and GSTT1 genotypes with T2DM patients and healthy control group

\begin{tabular}{|c|c|c|c|c|c|c|c|}
\hline \multirow[t]{2}{*}{ Genotypes } & \multicolumn{2}{|c|}{ T2DM } & \multicolumn{2}{|c|}{ Control } & \multirow[t]{2}{*}{$p$-value } & \multirow[t]{2}{*}{ OR } & \multirow[t]{2}{*}{$95 \% \mathrm{Cl}$} \\
\hline & $\mathrm{n}$ & $\%$ & $\mathrm{n}$ & $\%$ & & & \\
\hline \multicolumn{8}{|l|}{ GSTM1 } \\
\hline Positive & 16 & 18.4 & 13 & 14.9 & - & 1 & Reference \\
\hline Null & 71 & 81.6 & 74 & 85.1 & 0.542 & 0.780 & $0.350-1.737$ \\
\hline \multicolumn{8}{|l|}{ GSTT1 } \\
\hline Positive & 47 & 54.0 & 48 & 55.2 & - & 1 & Reference \\
\hline Null & 40 & 46.0 & 39 & 44.8 & 0.879 & 1.047 & $0.577-1.903$ \\
\hline \multicolumn{8}{|l|}{$\begin{array}{l}\text { Combination GSTM1 } \\
\text { and GSTT1 }\end{array}$} \\
\hline Positive/Positive & 10 & 11.5 & 7 & 8.0 & - & 1 & Reference \\
\hline $\begin{array}{l}\text { Positive/null and null/ } \\
\text { positive }\end{array}$ & 43 & 49.4 & 47 & 54.0 & 0.640 & 0.640 & $0.224-1.831$ \\
\hline Null/Null & 34 & 39.1 & 33 & 38.0 & 0.551 & 0.721 & $0.245-2.120$ \\
\hline
\end{tabular}

\section{Discussion}

GSH transferases (EC 2.5.1.18) also called historically as GST, lead to GST abbreviation that is widely used. GST is multifunction enzyme group that involved in detoxification of electrophilic substrates from oxidation through conjugation with GSH. The GSH conjugate is then transported to kidney to be excreted by urine as mercapturicacid. GST activity can be induced by several compounds, both endogenous and exogenous compound. The three major GST families that have been identified are mitochondrial GST, membrane-related microsomal GST and cytosolic GST. Cytosolic GST is found in almost all cells and organs cytosolic fraction, that is, kidney, lungs, and small intestine. In mammalians, GST in cytosol is classified in six classes namely $\alpha$ (alpha), $\mu$ (mu), $\pi$ (pi), $\theta$ (tetha), $\varphi$ (sigma), $\omega$ (omega), and $\zeta$ (zeta). Researcher has identified that the null variant is found in two members of GST, namely, GSTM1 and GSTT1. Several variations of GSTM1 and GSTT1 null homozygote have been observed in various ethnics [7], [20], [21].

This present study showed that the frequency of GSTM1 null genotype polymorphism was higher than GSTM1 positive in this population, but there was a different result in GSTT1 genotype. In Indonesia, studies about GSTM1 and GSTT1 gene variation have been done. The present study findings were consistent with the results reported by Amtha et al. (2009). According to their study in oral cancer population at several Jakarta hospital, it was found that the frequency of GSTM1 null was higher than GSTM1 positive, while the frequency of GSTT1 null was lower than GSTT1 positive [19].

This present study showed that the frequency of GSTM1 null genotype in T2DM patients was lower than healthy control group ( $81.6 \%$ vs. $85.1 \%)$, while the frequency of GSTT1 null genotype was higher in T2DM patients than healthy control group ( $46.0 \%$ vs. $44.8 \%)$. The frequency of GSTM1 and GSTT1 studies on T2DM versus healthy control group in various countries has shown varied results. A previous study in China was consistent with our present study which showed that the frequency of GSTM1 null genotype in T2DM patients was lower than healthy control group and the frequency of GSTT1 null genotype was higher in T2DM patients than healthy control group [22]. Studies in Romania and Egypt showed that the frequency of GSTM1 null genotypes and GSTT1 in T2DM patients was lower than healthy control group ( $47.6 \%$ vs. $48.0 \% ; 17.9 \%$ vs. $25.5 \%$ and $46.3 \%$ vs. $51.0 \%$; $33.3 \%$ vs. $35.3 \%$ ) [23], [24]. In contrary, different results were found in T2DM patients at India population. The previous studies showed that the frequency of GSTM1 null genotypes and GSTT1 in T2DM patients was higher than healthy control group [9], [25].

Each organism was originated from one cell. Inside the cell is a material that carries out genetic information called genetic material (gene) which found in nucleus. Gene in population level was evaluated through frequency, like calculating how often a certain variants gen came up in certain population [26]. Gene polymorphism was the appearance of genetic structure/genotype variationin a population. Similarities and differences in the frequency of genotype gene 
appearance in a population, compared to other populations, have an uniqueness that are affected by many factors. Frequency appearance of certain genotype is aimed to adapt and overcome the surrounding environment pressure for survival [27]. Genotype variation affects individual susceptibility to overcome/expose to diseases [28].

In this present study, GSTM1 null and GSTT1 null genotype had no risk of developing T2DM $(\mathrm{OR}=0.780 ; 95 \% \mathrm{Cl}=0.350-1.737 ; \mathrm{p}=0.542$ and $\mathrm{OR}=1.047 ; 95 \% \mathrm{Cl}=0.577-1.903 ; \mathrm{p}=0.879)$. A previous study in South Iranian population showed that the GSTM1 null genotype was found to be associated with T2DM but neither GSTT1 nor the combination of GSTM1 null and GSTT1 null genotype showed increased the risk of suffered T2DM [29]. In another study, a significant association between GSTM1 null genotype, GSTT1 null genotype and T2DM was observed [30]. A study conducted by Amer et al. (2011) in Egypt found that GSTM1 and GSTT1 carrying both null genotype were associated in increasing risk of T2DM (OR= 3.17; $p=0.009)$ [14].

GSTM1 and GSTT1 are the family of GST which is an important antioxidant. GSTM1 and GSTT1 are needed for GSH activity to protect cell against damage caused by xenobiotic and ROS accumulation. Gene polymorphism cause changes even loss in enzyme activity that was encoded by the gene [5], [21]. Loss of enzyme activity causes stress oxidation that cannot be muffled so that this condition is involved in arising T2DM [31]. Further investigation is needed to evaluate the association of GSTM1 and GSTT1 null genotype with GSTM1, GSTT1 enzyme activity and total antioxidant capacity levels in this population. We expected that the results of this study became a feedback for further research.

\section{Conclusion}

In summary, this study showed that GSTT1 null genotype, GSTM1 null genotype, the combination of GSTM1 null, and GSTT1 null genotype or combination of GSTM1 null and GSTT1 positive (or contrary) did not have any risk developing T2DM at Universitas Sumatera Utara Hospital, Medan.

\section{References}

1. Powers AC. Diabetes mellitus. In: Longo DL, Kasper DL, Jameson JL, Fauci AS, Hauser SL, Loscalzo J. Harrison's Endocrinology. $3^{\text {rd }}$ ed. United States: McGraw Hill Education; 2013. p. 261-307.
2. International Diabetes Federation. IDF Diabetes Atlas. $9^{\text {th }}$ ed. Brussels, Belgium: International Diabetes Federation; 2019. Available from: https://diabetesatlas.org/upload/resources/ material/20200302_133351_IDFATLAS9e-final-web.pdf [Last accessed on 2021 Sep 30].

3. Kementerian Kesehatan, Badan Penelitian dan Pengembangan Kesehatan. Hasil Utama Riskesdas. (Ministry of Health, Health Research and Development. Main Results of Riskesdas); 2018. Available from: http://dinkes.babelprov.go.id/sites/default/ files/dokumen/bank_data/20181228\%20-\%20Laporan\%20 Riskesdas\%202018\%20Nasional-1.pdf [Last accessed on 2021 Sep 01].

4. Phaniendra A, Jestadi DB, Periyasamy L. Free radicals: Properties, sources, targets, and their implication in various diseases. Indian J Clin Biochem. 2015;30(1):11-26. http://doi. org/10.1007/s12291-014-0446-0

PMid:25646037

5. Birben E, Sahiner UM, Sackesen C, Erzurum S, Kalayci O. Oxidative stress and antioxidant defense. World Allergy Organ J. 2012;5(1):9-19. http://doi.org/10.1097/ WOX.0b013e3182439613

\section{PMid:23268465}

6. Banerjee $M$, Vats $P$. Redox biology reactive metabolites and antioxidant gene polymorphisms in Type 2 diabetes mellitus. Redox Biol. 2014;2:170-7. http://doi.org/10.1016/j. redox.2013.12.001

PMid:25460725

7. Josephy PD. Genetic variations in human glutathione transferase enzymes: Significance for pharmacology and toxicology. Hum Genomics Proteomics. 2010;2010:876940. http://doi.org/10.4061/2010/876940

PMid:20981235

8. Suthar PC. Glutathione S-transferases: A brief on classification and GSTM1-T1 activity. Int J Pharm Sci Res. 2017;8(3):1023-7. http://doi.org/10.13040/IJPSR.0975-8232.8(3).1023-27

9. Datta SK, Kumar V, Pathak R, Tripathi AK, Ahmed RS, Kalra OP, et al. Association of glutathione S-transferase M1 and T1 gene polymorphism with oxidative stress in diabetic and nondiabetic chronic kidney disease. Ren Fail. 2010;32(10):1189-95. http:// doi.org/10.3109/0886022X.2010.517348

PMid:20954980

10. Cao T, Xu N, Wang Z, Liu H. Effects of glutathione S-transferase gene polymorphisms and antioxidant capacity per unit albumin on the pathogenesis of chronic obstructive pulmonary disease. Oxid Med Cell Longev. 2017;2017:6232397. http://doi. org/10.1155/2017/6232397

11. Dastjerdi AH, Behboudi H, Kianmehr Z, Taravati A, Naghizadeh $\mathrm{MM}$, Ardestani SK, et al. Association of glutathione S-transferase polymorphisms with the severity of mustard lung. Bioimpacts. 2017;7(4):255-61. http://doi.org/10.15171/bi.2017.30 PMid:29435433

12. Uddin MM, Ahmed MU, Islam MS, Islam MS, Sayeed MS, Kabir Y, et al. Genetic polymorphisms of GSTM1, GSTP1 and GSTT1 genes and lung cancer susceptibility in the Bangladeshi population. Asian Pac J Trop Biomed. 2014;4(12):982-9. http:// doi.org/10.12980/APJTB.4.2014APJTB-2014-0476 PMid:26529288

13. Yaghmaei B, Yaghmaei K, Jafarian M, Golmohammadi S. Genetic polymorphisms of glutathione S-transferase $\mathrm{Mu} \mathrm{1}$, glutathione S-transferase theta 1 , and glutathione S-transferase P1 in oral squamous cell carcinoma: A case-control study in Iranian population. J Orofac Sci. 2015;7(2):108-12. http://doi. org/10.4103/0975-8844.169762

14. Amer MA, Ghattas MH, Abo-Elmatty DM, Abou-El-Ela SH. Influence of glutathione S-transferase polymorphisms on Type-2 diabetes mellitus risk. Genet Mol Res. 2011;10(4):3722-30. 
http://doi.org/10.1007/s11033-013-2833-7

PMid:22058002

15. Rasheed MN, Hasan OM, Mahmood AS. Association of glutathione S-transferase (GSTM1, T1) gene polymorphisms with Type 2 diabetes mellitus (T2DM) in the Iraq patients. Iraqi J Biotech. 2015;14(1):176-81. http://doi. org/10.4103/0022-3859.68633

PMid:20739761

16. Syarifah S, Widyawati T, Hasni H, Sari MI, Rusdiana R, Hamdi T. The relation of haplotype ATP-binding cassette B1 (ABCB1) and gluthation S-transferase P1 (GSTP1) A313G gene with haematological toxicity in Indonesian breast cancer patients receiving chemotherapy. Bangladesh J Med 2021;2021:36. http://doi.org/10.5001/omj.2022.36

17. Farhat F, Sari MI, Chrestella J, Syari RP. The Association of GSTT1 Polymorphism with Total Antioxidant Status of Nasopharyngeal Carcinoma Patients. In: AIP Conference Proceedings. Vol. 23. AIP Publishing LLC; 2021. p. 120002. http://doi.org/10.1063/5.0045622

18. Farhat F, Sari MI, Chrestella J, Syari RP. The Chemical Changes in the Total Antioxidant Status and Biological Activity of GSTP1 Polymorphism on Nasopharyngeal Carcinoma Patients. Vol. 713. In: IOP Conference Series: Earth and Environmental Science. 2021. p. 012049. doi.org/10.1088/1755-1315/713/1/012049

19. Tantular R, Sri Muktiati N, Dwi Pratiwi S, Setijowati N. Glutathione S-Transferase M1 and T1 Polymorphisms Prevalence in Lung Cancer Patients in Malang, Indonesia. Respirology 2017; 22:1616. http://doi.org/10.1111/resp.13206_28

20. Oakley A. Glutathione transferases: A structural perspective. Drug Metab Rev. 2011;43(2):138-151. http://doi.org/10.3109/0 3602532.2011 .558093

PMid:21428697

21. Song Z, Shao C, Feng C, Lu Y, Gao Y, Dong C. Association of glutathione S-transferase $\mathrm{T} 1, \mathrm{M} 1$, and $\mathrm{P} 1$ polymorphisms in the breast cancer risk: A meta-analysis. Ther Clin Risk Manag. 2016;12:763-9. http://doi.org/10.2147/tcrm.s104339 PMid:27274261

22. Zhang J, Liu H, Yan H, Huang G, Wang B. Null genotypes of GSTM1 and GSTT1 contribute to increased risk of diabetes mellitus: A meta-analysis. Gene. 2013;518(2):405-11. http://doi. org/10.1016/j.gene.2012.12.086

PMid:23296061
23. Stoian A, Banescu C, Balasa RI, Motataianu A, Stoian M, Moldovan VG, et al. Influence of GSTM1, GSTT1, and GSTP1 polymorphisms on Type 2 diabetes mellitus and diabetic sensorimotor peripheral neuropathy risk. Dis Markers. 2015;2015:638693. http://doi.org/10.1155/2015/638693 PMid:26435566

24. Zaki MA, Moghazy TF, El-Deeb MM, Mohamed AH Mohamed NA. Glutathione S-transferase M1, T1 and P1 gene polymorphisms and the risk of developing Type 2 diabetes mellitus in Egyptian diabetic patients with and without diabetic vascular complications. Alexandria J Med. 2015;51(1):73-82. http://doi.org/10.1016/j.ajme.2014.03.003

25. Vats P, Chandra H, Banerjee M. Glutathione S-transferase and catalase gene polymorphisms with Type 2 diabetes mellitus. Dis Mol Med. 2013;1(3):46.

26. Venter JC, Smith HO, Adams MD. Citation classic the sequence of the human genome. Clin Chem. 2015;61(9):1207-8. http:// doi.org/10.1373/clinchem.2014.237016 PMid:26185218

27. Karki R, Pandya D, Elston RC, Ferlini C. Defining "mutation" and "polymorphism" in the era of personal genomics. BMC Med Genomics. 2015;8(1):1-7. http://doi.org/10.1186/ s12920-015-0115-z

28. Ismail S, Essawi M. Genetic polymorphism studies in humans. Middle East J Med Genet 2012;1(2):57-63. http://doi. org/10.1097/01.MXE.0000415225.85003.47

29. Moasser E, Kazemi-Nezhad SR, Saadat M, Azarpira N. Study of the Association between glutathione S-transferase (GSTM1, GSTT1, GSTP1) Polymorphisms with Type II diabetes mellitus in Southern of Iran. Mol Biol Rep 2012;39(12):10187-92. http:// doi.org/10.1007/s11033-012-1893-4 PMid:23014993

30. Tang ST, Wang CJ, Tang HQ, Zhang Q, Wang Y. Evaluation of glutathione $\mathrm{S}$-transferase genetic variants affecting Type 2 diabetes susceptibility: A meta-analysis. Gene. 2013;530(2):301-8. http://doi.org/10.1016/j.gene.2013.08.043 PMid:24008019

31. Volpe CM, Villar-Delfino PH, Dos Anjos PM, NogueiraMachado JA. Cellular death, reactive oxygen species (ROS) and diabetic complications review-article. Cell Death Dis. 2018;9(2):119. http://doi.org/10.1038/s41419-017-0135-z PMid:29371661 